\title{
22. CRETACEOUS RADIOLARIA IN THE EASTERN SOUTH ATLANTIC, DEEP SEA DRILLING PROJECT, LEG 40
}

\author{
Helen P. Foreman, Oberlin College, Oberlin, Ohio
}

\section{INTRODUCTION}

Leg 40 of the Deep Sea Drilling Project extended along the west coast of Africa from Capetown, South Africa, to Abidjan, Ivory Coast. Holes were drilled at six sites and Cretaceous cores recovered from four-Sites 361, 363, 364, and 365-which are situated as follows (Figure 1):

Site 361 : $35^{\circ} 03.97^{\prime} \mathrm{S}$; $15^{\circ} 26.91^{\prime} \mathrm{E}$, within Cape Basin, at a depth of 4549 meters.

Site $363: 19^{\circ} 38.75^{\prime} \mathrm{S} ; 09^{\circ} 02.80^{\prime} \mathrm{E}$, Frio Ridge segment of Walvis Ridge, at a depth of 2248 meters.

Site $364: 11^{\circ} 34.32^{\prime} \mathrm{S} ; 11^{\circ} 58.30^{\prime} \mathrm{E}$, Angola Basin, at a depth of 2448 meters.

Site $365: 11^{\circ} 39.10^{\prime} \mathrm{S} ; 11^{\circ} 53.72^{\prime} \mathrm{E}$, Angola Basin, at a depth of 3018 meters.

In general, Cretaceous radiolarians are missing or sparse and poorly preserved in the cores from these sites, and the uncommon good radiolarians are frequently either non-diagnostic or too few for stratigraphic interpretation. This is in marked contrast to Legs 17, 20, and 32 in the Pacific, all of which yielded Cretaceous cores with rich radiolarian faunas.

Age assignments here are, for the most part, based on information from Leg 32 (Foreman, 1975), where radiolarians occurred together with calcareous fossils, or where radiolarian-bearing non-calcareous cores could be correlated with radiolarian- and calcareous fossil-bearing cores from other holes. In that material, age data based on foraminifers and nannofossils agreed quite well from the Late Cretaceous through the Albian, but age assignments for older sediments tended to vary by about a stage, with the foraminifer data consistently giving an age about one stage younger than the nannofossil data. Since both these ages had to be considered in assigning ages to the radiolarian-bearing cores, some rather long ranges resulted. For the age assignments below, the assignment based on foraminifers is given first and then that based on nannofossils. Thus an assignment to the Aptian or Barremian-early Aptian indicates that the sample is correlated with Leg 32 sediments which are assigned to the Aptian, on the basis of foraminifers, and to the Barremian-lower Aptian on the basis of nannofossils.

Because of insufficient time for routine preparation of a sample from each core, samples were selected on the basis of reports from the shipboard scientists, indicating the presence of radiolarians or lithology and/or deposition depth favoring their presence. Occurrences and preservation of radiolarians in these selected samples appear below.

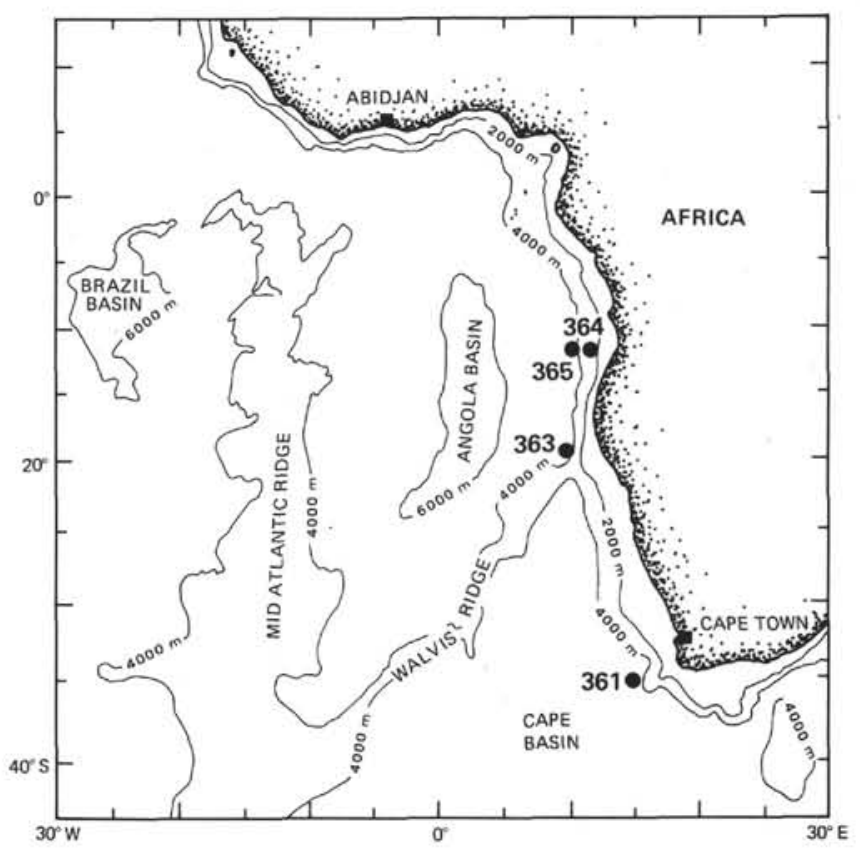

Figure 1. Location of DSDP Leg 40 Sites 361 and 363 to 365 .

Abbreviations for abundances are: C, common; F, few; $R$, rare; VR, very rare; - , absent. For preservation, the abbreviations are: G, good; M, moderate; and $\mathrm{P}$, poor.

\section{RADIOLARIANS AT EACH SITE}

\section{Site 361}

Radiolarians are generally absent; or when present, they occur mostly as casts of brown material or forms filled with brown material. Very rare, well-preserved radiolarians occur in only a few samples.

An age can be assigned only to Sample 28-6, 61-62 $\mathrm{cm}$, which, on the basis of a well-developed typical specimen of Eucyrtis micropora, is considered Barremian-early Aptian or Valanginian-Hauterivian (Eucyrtis tenuis Zone).

Table 1 below indicates the presence or absence of radiolarians in samples from Site 361, with abundances and preservation where appropriate.

\section{Site 362}

No sediments of Mesozoic age were cored. 
TABLE 1

Radiolarians at Site 361

\begin{tabular}{llc}
\hline $\begin{array}{c}\text { Sample } \\
\text { (Interval } \\
\text { in cm) }\end{array}$ & $\begin{array}{c}\text { Abundance of } \\
\text { Radiolarians }\end{array}$ & $\begin{array}{c}\text { Preservation of } \\
\text { Radiolarians }\end{array}$ \\
\hline $14-1,95-96$ & - & \\
$14-2,99-101$ & - & \\
$14-2,136-138$ & VR & P \\
$21-1,134-135$ & - & \\
$22-2,99-101$ & - & \\
$23-1,22-23$ & - & G \\
$27-2,6-7$ & VR & P \\
$27-2,57-58$ & R & P \\
$27-4,99-101$ & VR & P \\
27, CC & VR & G \\
$28-2,113-114$ & F & P \\
$28-6,61-62$ & R & G \\
$29-3,90-91$ & VR & P \\
$31-2,99-101$ & - & \\
$31-4,141-142$ & - & G \\
$32-2,80-82$ & VR & \\
$36-3,56-57$ & - & \\
\hline
\end{tabular}

\section{Site 363}

Good radiolarians are rare or very rare here and in many cases are too few to permit assignment more specific than Mesozoic or Cretaceous. The more abundant poor radiolarians are generally preserved as casts of brown material or filled with brown material.

Cores 22 through 25 may be assigned to the Late Cretaceous. Samples from these cores may be further identified as follows: 23-2, 99-101 cm, Campanian, probably late Campanian, on the basis of Dictyomitra regina (Campbell and Clark), together with fairly common forms belonging to the family Pseudoaulophacidae, and the absence of Amphipyndax enesseffi Foreman; 24-2, 99-101 cm, Campanian, probably late Campanian, on the basis of Neosciadiocapsa diabloensis Pessagno and Phaseliforma carinata Pessagno; 25-2, 99-101 cm, Santonian-Campanian, on the basis of Alievium gallowayi (White). Samples from Cores 26 to 30 , Section 5 contain no radiolarians or only non-diagnostic forms, too few for an assignment more precise than Mesozoic. Sample $30-6,27-29 \mathrm{~cm}$ is considered to be Barremian-Aptian (low in the Acaeniotyle umbilicata Zone), on the basis of the range of Spongosaturnalis horridus (Squinabol). Samples from Cores 31 to 33 may be identified only as either Cretaceous or Mesozoic, and those from Cores 34 to 39 as Barremian-Aptian to Barremian or ValanginianHauterivian, on the basis of the age of Core 30 and the presence of Amphipyndax stocki, which is known to appear first in the Barremian or the ValanginianHauterivian.

Table 2 below shows which samples from Site 363 contain radiolarians and indicates abundances and preservation where applicable.

\section{Site 364}

At least one sample each from Cores 13 through 22 was examined and found to contain no radiolarians. The following samples contain radiolarians as indicated
TABLE 2

Radiolarians at Site 363

\begin{tabular}{ccc}
\hline $\begin{array}{c}\text { Sample } \\
\text { (Interval } \\
\text { in cm) }\end{array}$ & $\begin{array}{c}\text { Abundance of } \\
\text { Radiolarians }\end{array}$ & $\begin{array}{c}\text { Preservation of } \\
\text { Radiolarians }\end{array}$ \\
\hline $22-1,99-101$ & VR & P \\
$23-2,99-101$ & F & M \\
$24-2,99-101$ & F & P \\
$25-2,99-101$ & F & G \\
$26-3,93-95$ & V & G \\
$27-1,74-76$ & VR & P \\
$28-5,87-89$ & - & G \\
$29-3,54-56$ & F & P \\
$30-1,36-38$ & - & \\
$30-2,10-12$ & VR & G \\
$30-3,141-143$ & VR & G \\
$30-4,76-78$ & F & P \\
$30-5,84-86$ & VR & G \\
$30-6,27-29$ & F & G \\
30, CC & R & P \\
$31-5,123-125$ & - & GR \\
$32-5,32-34$ & VR & G \\
$33-5,87-89$ & VR & G \\
$34-1,114-116$ & VR & G \\
$35-3,142-144$ & VR & G \\
$36-2,102-104$ & R & M \\
$37-5,78-82$ & F & P \\
$38-1,75-77$ & F & R \\
$39-2,86-88$ & R & P \\
$39-3,50-60$ & VR & G \\
\hline
\end{tabular}

in Table 3 below. Subsequent samples, at least one each from Cores 28 through 35 , contain no radiolarians -except Sample 35-3, 79-80 cm, which contains one fragment of a pyritized radiolarian.

No assignment more exact than Mesozoic was possible from the three samples with pyritized forms. Samples $25-5$, top and $26-6,56-58 \mathrm{~cm}$ are considered to be late Albian-Cenomanian, on the evidence of common Dictyomitra rotundata (Aliev). A single specimen of Acaeniotyle umbilicata in 25-5, top and a few in 26-6, 56-58 cm, which would indicate an age of at least late Aptian-early Albian, are considered to be reworked. The faunas in these two samples differ rather markedly, and thus 25-5, top may be considered late Albian-Cenomanian and 26-6, 56-58 cm late Albian. The latter assignment agrees with the data from this

TABLE 3

Radiolarians at Site 364

\begin{tabular}{lcc}
\hline $\begin{array}{c}\text { Sample } \\
\text { (Interval } \\
\text { in cm) }\end{array}$ & $\begin{array}{c}\text { Abundance of } \\
\text { Radiolarians }\end{array}$ & $\begin{array}{c}\text { Preservation of } \\
\text { Radiolarians }\end{array}$ \\
\hline $23-3,101-103$ & $\mathrm{~F}$ & Pyritized \\
$24-2,120-122$ & $\mathrm{~F}$ & Pyritized \\
$25-3,73-74$ & $\mathrm{~F}$ & Pyritized \\
$25-5$, top & $\mathrm{C}$ & $\mathrm{P}$ \\
$26-1,135-136$ & VR & P \\
$26-3,78-79$ & - & \\
$26-6,56-58$ & $\mathrm{C}$ & M-P \\
26, CC & F & P \\
$27-3,28-30$ & VR & P \\
\hline
\end{tabular}


report on foraminifers and nannofossils. Radiolarians in Samples 26, CC and 27-3, 28-30 cm seem to have the general aspect of those from the Aptian-Albian.

\section{Site 365}

One sample each from Cores 2-6 was examined. They contain no radiolarians. Sample 7-1, 41-49 cm contains a few fragments of pyritized radiolarians, and Samples $7-2,11-13 \mathrm{~cm}$ and $7, \mathrm{CC}$ contain no radiolarians.

\section{TAXONOMY}

A few radiolarians from Hole 363 , Cores 25 and 26 are described and illustrated here, partly because they contain the most varied fauna, and also because they represent a different late AlbianCenomanian fauna than has hitherto been described from Deep Sea Drilling Project cores. The typical late Albian-Cenomanian radiolarians, i.e., Dictyomitra veneta (Squinabol), D. pseudomacrocephala Squinabol, D. somphedia Foreman, and Lithomelissa petila Foreman, are all missing. Among the radiolarians, only Dictyomitra rotundata (Aliev) attests to their age.

\section{Spumellaria}

Amphibrachium leptum Foreman, new species

(Plate 1, Figures 8, 9)

[?]Spongodiscacea Pessagno, 1970, pl. 7, fig. A

Description: Shell spongy, comprising a rounded biconvex central area from which extend two polar arms. The inner part of the central area is raised slightly on both the upper and lower surfaces, and appears to be of looser, less dense material than the rest of the shell. It is joined to the outer part by a thin depressed band. The thicker outer band is dense and sturdy and generally remains intact when the more fragile inner parts have been damaged or entirely eroded. The two arms appear slightly asymmetric, in that the shorter one is more tapered, and the slightly longer one has more parallel sides and a blunt tip; their lengths are approximately half the width of the central area. They are fragile and frequently broken.

Measurements (based on 10 specimens from 364-26-6, 56-58 cm): Overall length $310-545 \mu \mathrm{m}$; width of central area perpendicular to plane of polar spines $225 \mu \mathrm{m}-285 \mu \mathrm{m}$.

Occurrence: In the Leg 40 material this species is very rare in 364 25-5, top late Albian-Cenomanian and few in $364-26-6,56-58 \mathrm{~cm}$ late Albian.

Remarks: Although it might seem from its shape that this species is the forerunner of Histiastrum anisum, the finer texture and the fragile central area of this form indicate fundamental structural differences. It is only provisionally assigned to Amphibrachium. pending further study of its relationship to other forms.

Etymology: From the Greek adjective leptos, meaning delicate.

\section{Crucella quadra Foreman, new species}

$$
\text { (Plate 1, Figure 10) }
$$

Description: Basically a four-armed cross with arms of approximately equal length, enclosed in a spongy patagium that when well developed completely fills the inter-arm area and covers the arms, thickening towards the ends, to form a spongy rectangle with equidistant sides. The patagium generally has a slight indentation, medianly along the margin of each side. The four arms are slender, show some distinct linear structure, and have a short three-bladed spine at each end.

Measurements (based on 10 specimens from 364-26-6, 56-58 cm): Greatest distance between two sides of rectangle measured parallel to a side, $300-530 \mu \mathrm{m}$.

Occurrence: In the material from Leg 40 , this form is rare in 364 26-6, 56-58 cm, late Albian. A rare similar form, smaller in size and with coarser meshwork, is known from an outcrop sample of the Gearle siltstone of Western Australia, probably Albian (Belford, 1958 ,

Etymology: From the Latin adjective quadrus, meaning square.

\section{Histiastrum anisum Foreman, new species}

(Plate 1, Figures 5-7)

Description: Shell spongy, with three to four irregularly developed arms; the central area tends to be circular on specimens with only three arms (Plate 1, Figure 5), and becomes more rectangular on specimens with a developing fourth arm (Plate I, Figure 6). On specimens with a more developed fourth arm, the base of each arm completely encloses the side from which it extends, except on one side that remains outwardly curved (Plate 1, Figure 7). The central area is raised on its upper and lower surface and is large in relation to the arms, which when well developed, taper gradually. Preservation is not good enough for a description of the arm tips, except that the blunt ends appear broken, and more pointed ends suggest a terminating spine. No internal structures were observed.

Measurements (based on 10 specimens from 364-25-5, top): On the plate the illustrations are oriented with the longest dimension comprising the vertical axis. Two dimensions are given here, one along this vertical axis, $320-630 \mu \mathrm{m}$, and the other, medianly perpendicular to this axis, $308-408 \mu \mathrm{m}$.

Occurrence: This species occurs only in Sample 364-25-5, top, late Albian-Cenomanian.

Remarks: Histiastrum anisum is distinguished from other spongy species with three and four arms by the irregular development of these arms, and by the large thickened central area, with at least one curved side giving a somewhat lopsided appearance. Not included in this broadly defined species is a rare co-occurring form with three regularly distributed, regularly shaped arms (Plate I, Figure 4). See Remarks under Amphibrachium leptum for discussion of its relationship to that species. It is only provisionally assigned to the genus Histiastrum, pending further study of its relationship to other forms.

Etymology: From the Greek adjective anisos, meaning unequal.

\section{Nassellaria}

Dictyomitra rotundata (Aliev) 1965 (Plate I, Figures 1-3)

Lithocampe rotundata Aliev, 1965, p. 61, pl. 11, fig. 6 .

Description: Shell of 9 to 10 segments, long and slender; proximal half conical, distal half tending to be cylindrical, and the last segment, when preserved, narrower, cylindrical or constricting, bowl-shaped. First two or three segments conical, with little or no change of contour externally; remaining segments inflated, with well-defined segmental strictures. A rather sharp change in contour may occur between the proximal noninflated segments and the distal inflated ones (Plate 1, Figure 2), or as in the form illustrated by Aliev (1965) and here (Plate 1, Figure 1), the change may be more gradual. Segments increase gradually in length distally. Cephalis poreless and the following one or two segments also poreless or with only a few pores and pore-shaped identations. Remaining segments with pores rounded, closely spaced, and irregularly quincuncially arranged.

Measurements (based on 12 specimens from 364-25-5, top and 26-6, $56-58 \mathrm{~cm}$ ): Length overall of specimens with 9 to 13 segments, 390 $500 \mu \mathrm{m}$; with 8 segments, $290-385 \mu \mathrm{m}$; greatest width, $145-200 \mu \mathrm{m}$.

Occurrence: In the Leg 40 material, this species is common in Samples 364-25-5, top, late Albian-Cenomanian, and 364-26-6, 56-58 $\mathrm{cm}$, late Albian. In the Leg 32 North Pacific material, it occurs in cores of the Albian-late Albian (foraminifer data) and upper Albianearly Cenomanian (nannofossil data). Aliev records this species from the late Albian and Cenomanian of northeastern Azerbaidzhan. He reports it co-occurring in the Albian with the foraminifers Verneuilina agalarovae Djaff. and Clavulina vulgaris Djaff. et Agal.

Remarks: Rare specimens here, and some from Leg 32 in the North Pacific, tend to be conical throughout their length.

\section{ACKNOWLEDGMENTS}

The author wishes to thank T.C. Moore Jr. for arranging for the shipboard sampling, and the Lamont-Doherty DSDP curatorial staff for filling post-cruise sample requests. The National Science Foundation provided financial support through grant DES 75-19288. 


\section{REFERENCES}

Aliev, Kh. Sh., 1965. Radiolyarii nizhnemelovykh otlozhenii severo-vostochnogo Azerbaidzhana $i$ ikh stratigraficheskoe znachenie (Radiolarians of the Lower Cretaceous deposits of northeastern Azerbaidzhan and their stratigraphic significance): Izd. Akad. Nauk Azerbaidz. SSR, Baku, p. 3-124.

Belford, D.J., 1958. Stratigraphy and micropaleontology of the Upper Cretaceous of Western Australia: Geol. Rundschau, v. 47, p. 629-647.

Foreman, H.P., 1973. Radiolaria of Leg 10 with systematics and ranges for the families Amphipyndacidae, Artostrobiidae, and Theoperidae. In Worzel, J.L., Bryant, W., et al., Initial Reports of the Deep Sea Drilling Project, Volume 10: Washington (U.S. Government Printing Office), p. 407-474.

1975. Radiolaria from the North Pacific, Deep Sea

Drilling Project, Leg 32. In Larson, R.L., Moberly, R., et al., Initial Reports of the Deep Sea Drilling Project, Volume 32: Washington (U.S. Government Printing Office), p. 579-676.

Pessagno, E.A. 1970. Mesozoic planktonic foraminifera and radiolaria. In Ewing, M., and Worzel, J.L. et al., Initial Reports of the Deep Sea Drilling Project, Volume 1: Washington (U.S. Government Printing Office) p. 607. 621.

\section{PLATE 1}

Albian-Cenomanian Radiolaria of Leg 40.

(All figures magnified $\times 133$ )

Figures 1-3 Dictyomitra rotundata.

1. 364-25-5, top. Cs 1 , W 51/0.

2. $364-25-5$, top. Cs 1 , Y $30 / 2$.

3. $364-26-6,56-58 \mathrm{~cm}$. Cs 2 , E $20 / 0$.

Figure $4 \quad$ Gen. and sp. indet.

$364-25-5$, top. Cs $2, \mathrm{~V} 22 / 0$.

Figures 5-7 Histiastrum anisum.

5. 364-25-5, top. Cs 2, B 35/0.

6. 364-25-5, top. Cs 2 , M 66/0.

7. 364-25-5, top. USNM 240330. 054/0. Holotype.

Figures 8,9 Amphibrachium leptum.

8. $364-26-6,56-58 \mathrm{~cm}$. Cs 2 , E $48 / 2$. Side view.

9. 364-26-6, $56-58 \mathrm{~cm}$. USNM 240331. W21/1. Holotype.

Figure $10 \quad$ Crucella quadra.

364-26-6, 56-58 cm. USNM 240332. G 45/0.

Holotype. 
PLATE 1
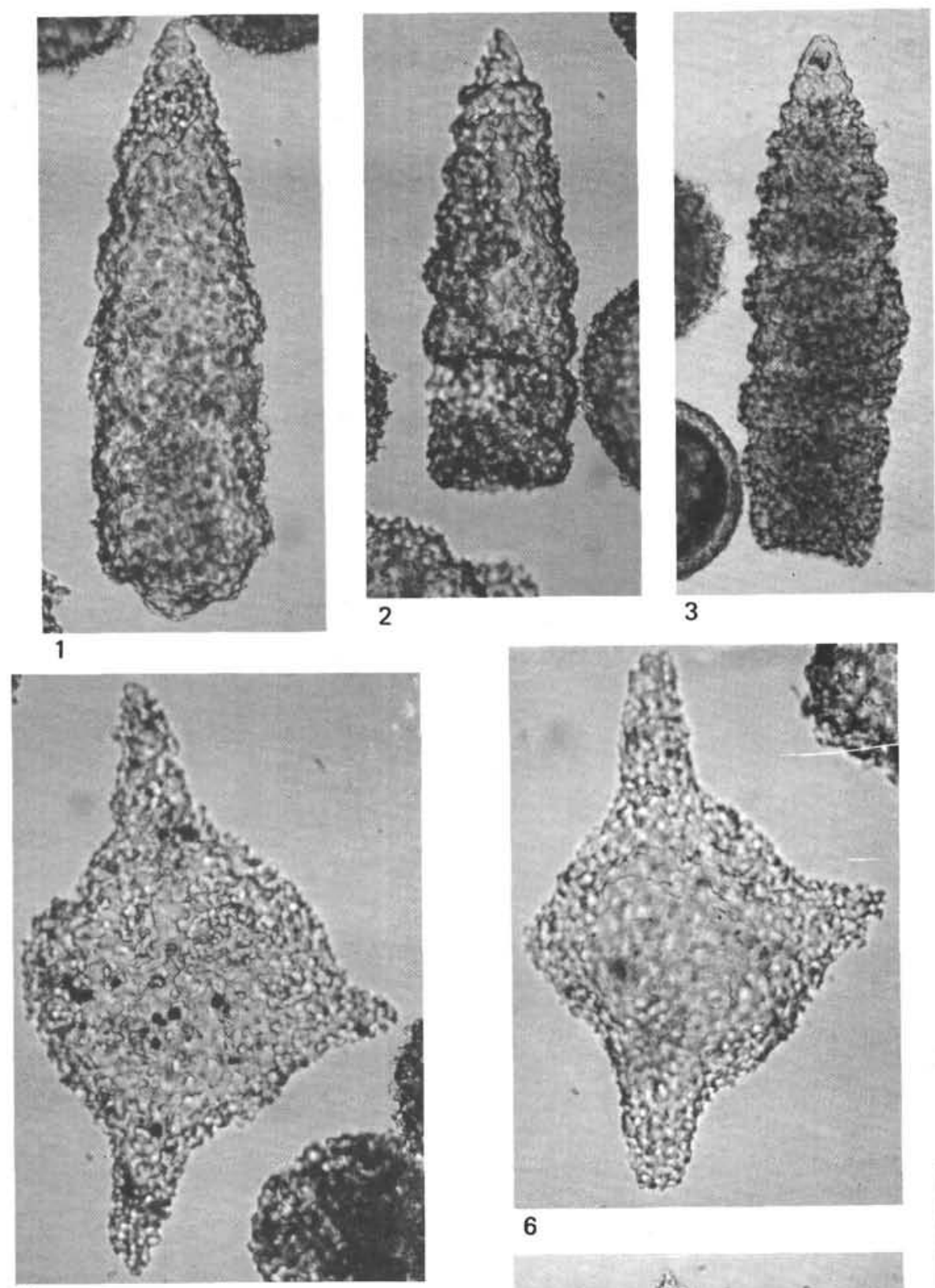

5

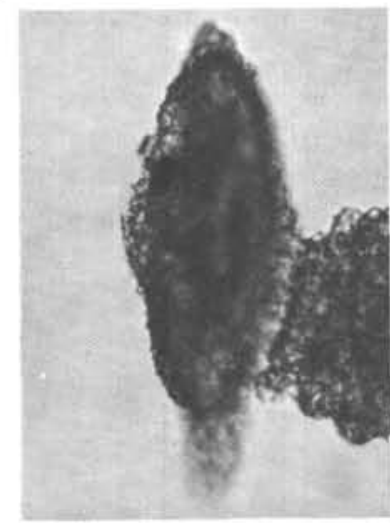

8
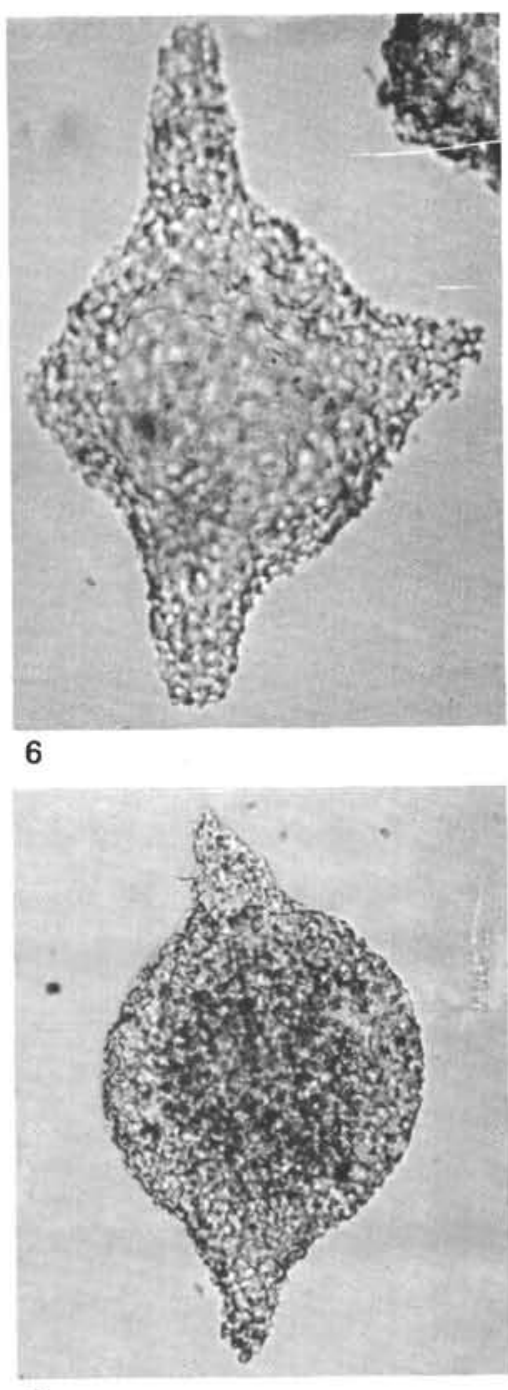

9

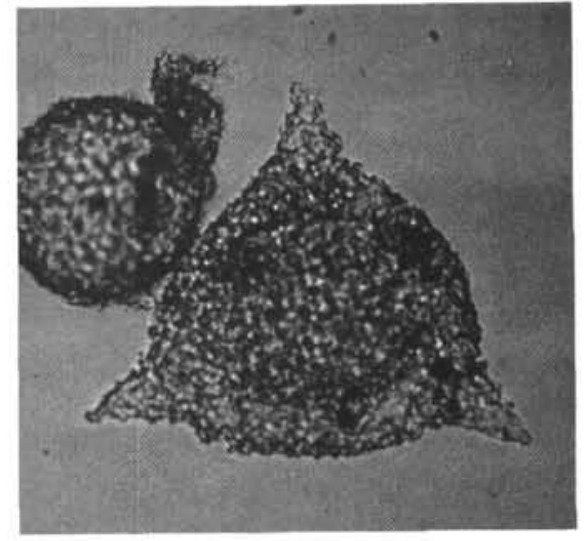

4
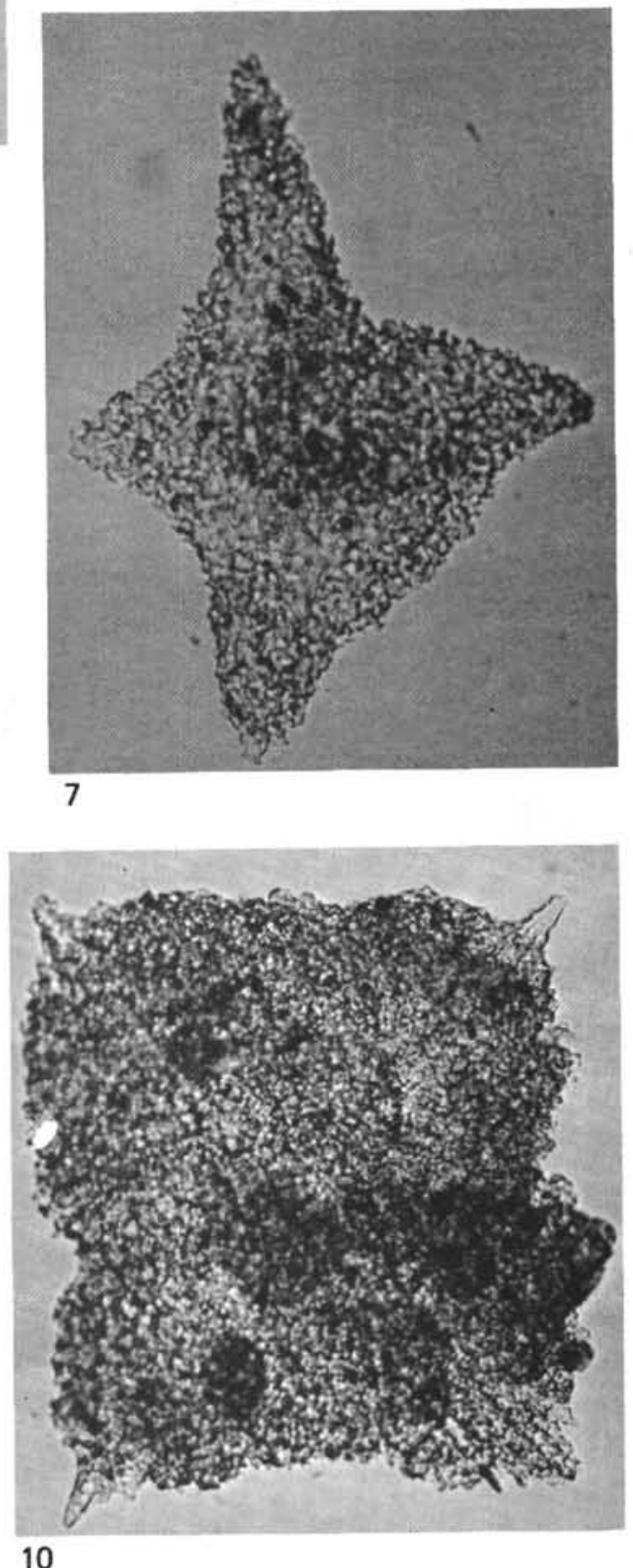